\title{
Inspektor, nebo ochránce? Působení Čeňka Kramoliše jako okresního školního inspektora $v$ době první světové války na Hranicku
}

\section{Helena Kovářová ${ }^{a}$ \\ a Muzeum Komenského v Přerově kovarova@prerovmuzeum.cz}

DOI 10.15240/tul/006/2021-2-007

\section{Úvod}

Na počátku 20. století byli okresní školní inspektoři nejnižší jednotkou systému dozoru nad úrovní výuky elementárního školství v českých zemích. Při pravidelných prohlídkách

kontrolovali nejen styl a obsah výkladu učitele, ale také stav školní budovy, vybavení tříd a kabinetů, pravidelnost docházky žáků atd. Okresní školní inspektoři byli jmenováni ministerstvem kultu a vyučování na návrh zemských školních inspektorů a zemských školních rad, jejich funkční období trvalo šest let. Okresní školní inspektoři byli členy okresní školní rady, na jejích pravidelných měsíčních zasedáních podávali zprávy o provedených kontrolách na jednotlivých školách okresu, hodnotili pedagogické schopnosti učitelů, stejně jako úroveň znalostí žáků v různých obcích. Všechny učitele okresu znali osobně. Při jednání s místními školními radami také získávali přehled o poměrech v obcích.

$\mathrm{Z}$ tohoto důvodu můžeme říci, že nebylo znalejší osoby ohledně stavu okresního školství - jeho každodenního chodu, života učitelů, postavení škol v tehdejších aktuálních společensko-politických podmínkách. Pomocí „biografické metody“ můžeme rekonstruovat nejen život inspektorů, ale i jimi kontrolovaných škol a zásadních aktérů školství. Následující studie je právě jedním z pohledů do každodenních úkolů práce inspektora a rovněž tak i do života tehdejších obecných a měštanských škol, postavení učitelstva a národnostních otázek ve školství. 


\section{Jmenování do funkce inspektora}

V roce 1907 byly na Moravě v národnostně smíšených okresech zřízeny dvě okresní školní rady, jedna česká a druhá německá. $V$ tomto roce také skončilo šestileté funkční období stávajících okresních školních inspektorů. Pokud již věk stávajícího inspektora přesáhl hranici 60 let, nebyl již znovu navržen do seznamu kandidátů. Také ve školním okrese Hranice, městě na střední Moravě, vznikly v roce 1907 dvě okresní školní rady a stávající inspektor Rudolf Kadeřávek odcházel na odpočinek. Do funkce českého okresního školního inspektora byl nově jmenován učitel měštanské školy ve Vyškově Čeněk Kramoliš (1862-1949).

Čeněk Kramoliš byl již tehdy známým spisovatelem povídek z venkova a historických románů. Jedním z jeho pozdějších literárních děl jsou memoáry - nabízí se tak jedinečná možnost doplnit oficiální dokumenty úřední povahy osobními vzpomínkami. Zajímavé je například samotné jmenování do funkce okresního školního inspektora. Sám Kramoliš žádal v roce 1907 o místo ředitele měštanské školy v Novém Rousínově na jižní Moravě. Přestože měl skvělé vysvědčení a splňoval všechny předpoklady, ředitelem se stal jeho protikandidát. Jak se dozvěděl od kolegů, důvodem byla osobní př́mluva a přání místodržitele (Kramoliš, 1948, s. 92-93), nejvyššího představitele státní správy v Markrabství moravském. Kramoliš proto očekával, že se mu vrátí jeho žádost ze zemské školní rady jako zamítnutá, ale místo toho obdržel jmenovací dekret do funkce okresního školního inspektora v Hranicích na střední Moravě od 1. 1. 1908. Přestože o tuto pozici nežádal, bral ji jako satisfakci za upřené místo ředitele měštanské školy.

Jeho vzpomínky na seznámení s tamním okresním hejtmanem Emilem Wychodilem z Hanaburku dokládají, jak důležitou roli hrály osobnostní rysy a dobré osobní vztahy i v době přísně dodržované služební hierarchie. Hejtman byl z titulu své funkce také předsedou okresní školní rady. O osobě nového inspektora, svého podřízeného, se dopředu informoval a hned při prvním setkání mu sdělil: „Svědomitost v práci vám nebudu doporučovati, tu máte prý vrozenou. Ponechám vám ve školské inspektorské práci úplnou volnost, ale též budete za vše sám zodpovědný. Budu vás považovati za milého spolupracovníka, ale kdybyste mne jen jednou zklamal, bylo by po důvěře. To si 
pamatujte“ (Kramoliš, 1948, s. 97). Podle Kramolišových memoárů se hejtman této zásady držel a do rozhodování školských záležitostí nezasahoval, schvaloval všechny inspektorovy návrhy. Inspektor se snažil všechna svá rozhodnutí vysvětlit a odůvodnit. Kramoliš pracoval velmi pečlivě, systematicky, vždy s dưrazem na rozvoj českojazyčného školství. Již používáním podoby jména Čeněk, která je českým ekvivalentem k jeho křestnímu jménu Vincenc, vyjadřoval svou příslušnost k českému národu.

\section{Změny v hodnocení učitelů novým inspektorem}

Rudolf Kadeřávek, předešlý inspektor ve školním okrese Hranice, byl učitelem na německém gymnáziu a zaznamenával do vizitačních protokolů jen strohé a veskrze kladné hodnocení učitelů, např. „metoda správná, výsledky vyučování uspokojivé“. Výtky se objevovaly jen zř́dka a týkaly se formálních záležitostí, např. nutnosti nakoupit nové učební pomůcky. Nebo k hodnocení „dostatečně“ připojil poznámku, že se „očekává najisto“ zlepšení. ${ }^{1}$ Po nástupu nového inspektora Čeňka Kramoliše se styl hodnocení v protokolech změnil. Sám měl 23 let praxe výuky na obecných školách. Jeho nároky na učitele byly daleko vyšší než u předchozího inspektora, hodnotil je mnohem přísněji, zejména z pohledu znalostí žáků a jejich prospěchu. Hned při první inspekci do oficiálního protokolu poznamenal u Šimona Košuta, nadučitele s delší praxí v malé obci Daskabát: „Zdá se býti pohodlný. [...] Žáci ještě koncem dubna př́liš užívají při počítání prstů, starší jsou v násobilce slabi““2 . Kritiku však dokázal spojit s oceněním, např́iklad u podučitele Josefa Vilímka na téže škole: „Mluvnice - upozorňoval náležitě na pravopis. Fyzika - málo př́íkladů a upotřebení. Milé jednání. Rychle mluví. Rychlému mluvení budiž odvykáno“33. Hned následující školní rok pak u kritizovaného učitele Košuta zapsal: „Přísné zakročení po minulé inspekci jevilo velmi dobrý výsledek, napnul síly, co mohl“. Inspektor „projevil radost nadučiteli, že letos měl výsledek uspokojivý, 
a hleděl ho povzbudit k další činnosti. “4 V dalších letech učiteli Košutovi vytýkal nadužívání automatických frází, na každou žákovu odpověd” reagoval: „To se ví!“ nebo „To se rozumí". Naopak u nového, mladého výpomocného učitele Bohumíra Růžičky poznačil: „Měl denní přípravu - třídní kniha pěkně psána, bude z něho dobrý učitel.“5 Velmi také chválil pedagogické vedení ve všech předmětech mladou učitelkou Janou Valentovou. Jeho hodnocení byla nekompromisní, a to jak z pohledu kvality vzdělání, tak správného vedení úředních knih a dalších formálních záležitostí školy.

Během svého působení ve školním okrese Hranice se snažil o rozšíření a zkvalitnění vzdělávací sítě českých škol, at̉ už zřizováním nových tříd (tzv. poboček) na školách nejnižšího stupně (obecných školách) a s nimi spojených nových učitelských míst, nebo navazujících pokračovacích kurzů pro absolventy měštanských škol. Po třech letech inspektorské praxe sepsal Čeněk Kramoliš Příručku pro učitele, místní a c. k. okresní školní rady s podtitulem Praktický doplněk $k$ Příruční knize školních zákonů a předpisů (Kramoliš, 1911). V úvodu vyjádřil přání, aby v př́ručce uvedené vzorové stanovy a učební osnovy usnadnily zakládání různých kurzů a škol.

V Hranicích proběhl na přelomu 19. a 20. století politicko-národnostní boj o správu města. Nakrátko získala úřady německá strana. Školy a školské záležitosti byly dưležitým bodem národnostního politického zápasu o správu města (Bartovský, 1906, s. 129-154; Kadlec, 2017, s. 80). Několik let před příchodem Čeňka Kramoliše v Hranicích ve volbách zvítězili představitelé české národní strany a cesta $\mathrm{k}$ dalšímu rozvoji českojazyčného školství tak byla otevřená. Za pět let pưsobení Čeňka Kramoliše ve funkci okresního školního inspektora vzniklo 38 nových učitelských míst v českých elementárních školách. Dokázal učitele v celém okrese nadchnout nejen pro intenzivnější práci ve škole, ale i pro osvětovou činnost určenou široké veřejnosti. Byly pořádány výstavy žákovských prací, exkurze, výlety, zájezdy, školní slavnosti, 
divadelní představení, besídky s rodiči, vysazovány ovocné stromy a přibývalo také veřejných knihoven při školách, ze kterých učitelé pưjčovali knihy i dospělým (Jubileum. Moravská orlice, 1912, s. 2-3). Jeho zásluhou byly v Hranicích založeny česká ženská průmyslová (také rodinná) škola a česká pokračovací škola pro učednice (Kramoliš, 1948, s. 111-112).

\section{Jediné disciplinární ŕízení s učitelem}

Celých šest let řešil inspektor Kramoliš prohřešky učitelů pouze ústním napomínáním a výstrahou. V květnu 1914 však podal svůj první a také poslední podnět pro zahájení disciplinárního řízení s učitelem Vladimírem Hapalou. ${ }^{6}$ Ten měl být zjištěn jako autor urážlivého článku určeného k otištěnív místních novinách Hlasy z Pobečví. Text s názvem $V$ dobách protekce vytýkal inspektoru Kramolišovi, že na místa učitelů přijímá uchazeče z jiných okresů a protekční žadatele. Sám Vladimír Hapala ale do hranické školy přišel z jiného okresu právě zásluhou Kramoliše, když přihlédl k sociální a finanční situaci rodiny, pro kterou společné bydlení znamenalo značnou úsporu. Za bratra se přimlouval učitel Richard Hapala, který již v Hranicích působil.

Kramoliš podezrríval již dříve učitele Vladimíra Hapalu, že napsal několik smělých až drzých článků do novin, ale věřil jeho ujištování, že tomu tak není. Nyní se Kramolišovi dostal do ruky rukopis $V$ dobách protekce. Zjistilo se, že jej opisoval žák obecné školy podle předlohy, kterou mu dal učitel Vladimír Hapala. Při vyšetřování Hapala uváděl, že dal žákovi opisovat text z novin, a není tedy jeho autorem. Vysvětlení, že zamýšlel opis poslat kolegovi do Vyškova, před komisí neobstálo. I kdyby tomu tak bylo, neměl dávat urážlivý text opisovat žákovi. Nakonec se podařilo dospět ke smírnému řešení, Vladimír Hapala dal na své náklady otisknout omluvu (Prohlášení), a to nejen v regionálních novinách (Hlasy z Pobečví, Hranicko-Lipnický Obzor), ale také ve Věstníku Ústředního spolkujednot učitelských na Moravě. Inspektor Kramoliš 
mu pak odpustil a bylo zastaveno také disciplinární ŕízení. Stalo se tak tři dny po vyhlášení války, která přerostla v mezinárodní konflikt známý jako první světová válka.

\section{Hodnocení učitelů v období války}

Po vypuknutí války v červenci 1914 však okresnímu školnímu inspektorovi přibyly zcela nové problémy v oblasti péče o školu. Byl nucen řešit velmi prekérní a choulostivé situace související s napjatou atmosférou zákazů a udavačství, dále pak problémy s udržením kvality výuky, a to hned z několika důvodů. Kvưli nedostatku učitelů odváděných do armády musela být zaváděna střídavá výuka tříd nebo dokonce celých vesnických jednotřídek. Na mnoha místech se učilo v nevhodných prostorách a chyběly učební pomůcky v důsledku zabrání školní budovy vojskem. Často se nedařilo najít adekvátní náhradní prostory pro výuku. Musela být udržována velmi př́ísná kázeň, a dokonce i v hodinách se muselo mluvit potichu. Př́ísné podmínky soukromých pronajímatelů dokonce $\mathrm{v}$ jednom případě zabránily řádnému průběhu inspekce, protože do zamčené budovy nebyl vpuštěn (Kovářová, 2014, s. 26-27). Kramolišovi se podařilo intervencí prímo u vojenského velitele v zabrané budově školy města Drahotuše zajistit aspoň jednu třídu pro střídavé vyučování. Na další požadavky mu armádní důstojník odpověděl: „Starost o vojsko je nyní potřebnější než starost o žáky. Bud'te rád, že tolik jsem vám povolil“ (Kramoliš, 1924, s. 10). Také učitel Hubert Karlíček ve vesnici Velká po zabrání celé budovy armádou do kroniky poznamenal: „Protestovat proti tomu bylo marné. Naše byty se pánům zamlouvaly, přišli vojáci, zařídili a postavili, co potřebného, a přeměna byla hotova. “8

V roce 1916 situaci ještě více zkomplikoval zákaz používání dosavadních čítanek. Na dodání nových se čekalo několik měsíců. Mnohde nebylo čím knihy nahradit, a pokud žáci nevlastnili bibli či katechismus, nemohli číst. Kvưli zdražení papíru učitelé obtížně obstarávali pro žáky sešity. Ve výjimečných př́ípadech se na týden či dva 
výuka psaní zastavila. Další překážkou kvalitní výuky byla povinná služba učitelů u státních úřadů, kde pracovali jako písaři, byli pověřováni sepisováním zásob, půdy, organizováním sbírek, rekvizic a upisováním válečných půjček.

Sami učitelé si byli vědomi, že není možné dosáhnout výsledků srovnatelných s výukou v předválečných letech. Okresní školní inspektor sice při kontrolách přihlížel k objektivním překážkám, ale dobrá hodnocení uděloval jen na základě viditelné snahy a píle učitelů. V městě Drahotuších stejně jako před válkou a po jejím skončení oceňoval inspektor ředitele Františka Zapletala jako výborného metodika. Naopak u druhého učitele, Čeňka Maráka, zaznamenal inspektor své výhrady. Před válkou jej chválil za zařazování praktických výkladů do př́rodopisu a naopak při inspekci v roce 1917/1918 za něj převzal výuku o vápenci a ukázal, jak učit praktičtěji a srozumitelněji ${ }^{9}$. Mưžeme se jen dohadovat, že tato změna mohla být způsobena vnějšími, válečnými okolnostmi. Učitel Marák byl velmi činorodý člen organizace Sokol a český vlastenec. Oba jeho synové bojovali na frontě a zemřeli v mladém věku. Po válce se Čeněk Marák dokázal s tragickými událostmi vyrovnat, angažoval v místní politice, stal se starostou a ředitelem školy (Kovářová, 2012, s. 78-81).

Kvưli nedostatku učitelů musely školské úřady sáhnout i k nestandardním řešením. Například učitelka ženských ručních pracív Drahotuších Terezie Šejdová dostala povolení vyučovat za dozoru ředitele také ostatní předměty. Před válkou o ní inspektor Čeněk Kramoliš zapsal, že je „nábožná, slabého zdraví a zadání za ni přečítají žákyně“10. Její pedagogické metody v době válečného provizoria hodnotil inspektor jako neurčité, ale oceňoval snahu a výsledky pro něj byly dostačující. Dokázal rozpoznat osobní limity jednotlivce.

9 OŠV Hranice, inv. č. 199. SOkA Přerov.

10 Tamtéž. 


\section{Snahy o návrat odvedených učitelů}

Okresní školní inspektor usiloval o návrat (vyreklamování) odvedených učitelů z armády do škol. Všechny žádosti se z místodržitelství v Brně vracely jako zamítnuté, a to nejen pro školní okres Hranice, ale pro celou Moravu. Odvedení učitelé Kramoliše v dopisech prosili o pomoc a zastání, nebot jiné zemské úřady monarchie určitou část učitelů $\mathrm{z}$ armády přece jen propouštěly. Inspektor proto podával žádosti opakovaně, ale bez výsledku. Nakonec se bez porady s okresním hejtmanem vydal do Brna požádat moravského místodržitele o pomoc osobně. Místodržitel Oktavian Regner von Bleyleben však odpověděl: „A vy jste okresní školní inspektor? Vy jste loajální inspektor, že přicházíte s takovou žádostí? My nepotřebujeme nyní učitelů, potřebujeme vojáků a vy tak je k srdnatosti povzbuzujete? Jděte!“ (Kramoliš, 1924, s. 51-52). Teprve později vyšlo najevo, že k moravskému místodržiteli se neodvážili přijít s žádostí o reklamaci vojáků ani poslanci. Výtka nedostatku loajality mohla mít pro okresního školního inspektora fatální následky. Kvưli věku (53 let) se na něj sice nevztahovala povinnost nastoupit $\mathrm{k}$ armádě, ale proti odvolání $\mathrm{z}$ funkce chráněn nebyl. Osobnostní rysy v tomto případě silně ovlivnily fungování státního úřadu, jak se ukázalo po odchodu Regnera von Bleyleben a návratu předválečného místodržitele Moravy Karla Heinolda. Ten byl na Moravě vnímán jako oblíbená osobnost a politik ochotný ke kompromisům. Záhy po jeho nástupu v roce 1915 se dařilo ty nejpotřebnější učitele vyreklamovat a řešit tak nejpalčivější problémy chodu škol, jako bylo střídavé vyučování jedním učitelem na vesnických školách vzdálených několik kilometrů. Stalo se tak v době, kdy ve školním okrese Hranice chyběla již polovina učitelů a reálně hrozilo zavírání škol.

Z dochovaných inspekčních protokolů válečných let 1914-1918 vyplývá, že se Kramoliš dál snažil udržet kvalitu výuky a nekompromisně pedagogům vytýkal chyby. Vyreklamovaného učitele Jana Matějíčka z Podhoří káral za liknavý způsob vedení úředních knih (třídní kniha, matrika a kronika) slovy: „Zdá se, že Vás učitelský stav netěší, že jste 
učitelem jen proto, abyste měl plat “"11. Tento učitel se sice na čas polepšil, ale špatné výsledky vykazoval i v poválečných letech 1922 a 1923.

\section{Udavačství a žaloby na učitele}

Velmi závažným problémem byla udání politického charakteru, která přicházela okresnímu hejtmanovi a týkala se chování učitelů na veřejnosti. Okresní školní inspektor se snažil učitele chránit před mocí vojenských úřadů a zvůli militarizovaného společenského života. Přicházelo mnoho politických udání, že se některý z učitelư či některá učitelka dopustili protistátního činu, bud'bylo vysloveno podezření na špionáž, či na velezradu. Velkou výhodou se ukázala být vzájemná důvěra a výborné pracovní vztahy okresního hejtmana a inspektora. Hned na začátku války upozornil hejtman Emil Wychodil z Hanaburku inspektora Kramoliše: „Jednejte rozvážně, hlavou zed’ neproboříme, a co můžeme, učiníme na obranu lidí, škol a dětí. Ale to půjde jen ztěžka a jen za souhlasu vojenského, který bude nyní vládnouti. Budte opatrný na svou řeč a skutky: všude budou uši“ (Kramoliš, 1924, s. 8).

Tuto radu porušila Kramolišova dcera Milada, která promluvila na nádraží na zajatého důstojníka rusky. Četníci naštěstí neznali jméno slečny a hejtmanovi se podařilo vyšetřování umlčet. Přišla ale i udání na konkrétní učitele či učitelky, například pro vlastizrádné chválení Srbů. Hejtman se v takovém případě radil s inspektorem o dalším postupu. Pokud byla žaloba sdělena pouze ústně, snažili se, aby se nedostala do písemných záznamů vojenských úřadů a řešili ji osobní domluvou. Další udání se týkala například nedůvěry učitelů ve válečné půjčky, štvaní polských uprchlíků proti občanům či nerozvážných řečí učitele Huberta Karlíčka v „hospodě“, „jako by se v Rakousku ani doma necítil“" (Kramoliš, 1924, s. 82). Karlíček byl Kramolišův spolužák, proto se i tuto situaci snažil vyřešit ústní dohodou s osobou, která přestupek ohlašovala, a samozřejmě napomenutím učitele. Před válkou pưsobil Karlíček jako redaktor místních novin, které kvůli cenzuře přestaly vycházet. Nejstarší syn, nadějný student, mu zemřel během vojenské 
služby. Učitel Karlíček se do konfliktu s vojenskou mocí mohl dostat i vícekrát, nebot podle pozdějších záznamů obecní kroniky zpíval se sousedy z Velké píseň Domov můj v roce 1916 po dobytí Bukurešti a smrti císaře (Nebeský, 2010, s. 120). Ovšem stalo se tak ve sklepě hostince a nikdo je neudal.

Okresní hejtman a inspektor se museli vypořádat i se závažnými žalobami na učitele, které př̌řly od četnictva. Například učitelka Rưžena Langová z Lipníka byla obviněna, že děti ve škole učila zpívat ruskou hymnu (Kramoliš, 1924, s. 64-68). Nakonec se ukázalo, že událost se týká roku 1885, kdy se hymna šiřila se souhlasem ministerstva u př́íležitosti setkání císaře Františka Josefa I. a ruského cara Alexandra III. v Kroměřízii. Na učitelku Janu Valentovou z Velkého Újezdu přišlo udání, že nenaučila děti zpívat rakouskou hymnu. Při zkoušce ve škole však žáci zpívali inspektorovi bezchybně. Zjistilo se, že děti hymnu nezpívaly v kostele. Ovšem v kostele docházelo ke svízelné situaci, neboṫ se současně zpívalo česky a německy, často i státní úředníci při zpěvu raději mlčeli. Správa školy proto upozornila žáky na nutnost zpěvu hymny v kostele, někde to dokonce kontrolovali vojenští důstojníci. Nejzávažnější udání se týkalo učitelky Marie Novákové a jejích dvou sester, také učitelek. Na jednu z nich si stěžoval důstojník armády, že přála vítězství nepřátelům, konkrétně Srbům. Žádal, aby hejtman podal hlášení armádnímu velitelství. Jednalo se již o druhé udání na učitelku Novákovou a zdálo se, že je ztracena. Inspektor poradil hejtmanovi jediné možné řešení - zařídit, aby žaloba byla podána, ale nebyla doručena. Dokonce přišla žaloba na samotného Kramoliše, že v restauraci pronesl protistátní výroky. Díky nadstandardním vztahům se věci ujal okresní hejtman a udání se mu podařilo urovnat. Inspektora dưrazně napomenul, že okna, dveře, zdi i vítr mají uši (Kramoliš, 1924, s. 80-81, 99).

Kramoliš usiloval o zmírnění dopadů nejrůznějších nařízení na učitele a uvědomoval si nesnáze, které jim způsoboval výkon úředních povinností $v$ rámci sociálních vztahů místního společenství, zejména ve vesnickém prostředí. Učitelé byli mimo jiné ustanovováni jako komisaři při soupisech půdy a odhadư úrod nebo rekvizicích potravin. Hrozilo, že si učitelé proti sobě popudí hospodáře, at by byla jejich práce 
sebespravedlivější. Inspektor Kramoliš proto dbal, aby nikdo nebyl jmenován ve své domovské obci, aby nebyly narušeny jeho vztahy se sousedy, což by mohlo ovlivnit i celkové prostředí školy. Přesto vznikaly konflikty například při upisování válečných půjček. Učitel Dřímal z obce Olšovec si v červnu 1918 inspektorovi stěžoval, že hospodáři již nechtějí pưjčku upisovat, ani pod pohrůžkou předvolání na hejtmanství. Učitel proto žádal inspektora, aby je nahlásil podle seznamu a dva nejvzdornější aby pro př́íší půjčku jmenoval do komise. Toto jednání šlo proti Kramolišově přesvědčení. Lze se jen dohadovat, že věc prodiskutoval s hejtmanem a odložil. Text učitelova dopisu pak přeškrtnul a prázdný rub papíru později použil pro zápis odlišných záležitostí a založil do složky školy v jiné vesnici Jindřichov ${ }^{12}$.

V atmosféře cenzury, všeobecného strachu a nedůvěry na počátku války označil moravský místodržitel Oktavian Regner von Bleyleben na schůzi všech okresních hejtmanů české učitele za nespolehlivý, neloajální a podvratný živel, se kterým je potřeba jednat př́sně a bezohledně (Skýpala, 1919, s. 3; srov. Pohan, 1919, s. 3). Inspektor Kramoliš se proto rozhodl zasílat zemské školní radě a prezidiu, tedy kanceláři místodržitele, přehledy pomocné a vlastenecké činnosti učitelů okresu, aby zmírnil předpojatost vioči českým učitelům. Jak již bylo řečeno, ani tyto seznamy neobměkčily smýšlení místodržitele o učitelích a změna nastala až s personální výměnou v této funkci.

\section{Vyznamenání inspektora a období po skončení války}

Okresní školní inspektor Čeněk Kramoliš za svou činnost v roce 1916 obdržel vyznamenání. Okresní hejtman Wychodil jej tímto způsobem chtěl odměnit za zodpovědnou a pečlivě vykonávanou práci. Efekt ale nebyl takový, jaký očekával. Hejtman postupoval přesně podle systému hodnostních tříd, které braly v potaz především dosažené vzdělání. Kramoliš tak měl nárok pouze na válečný kříž za civilní zásluhy III. tř́ídy, který dostávali i nižší kancelářští úředníci. Považoval to za znehodnocení inspektorské funkce a učitelského stavu. Typ uděleného

12 OŠV Hranice, inv. č. 218. SOkA Přerov. 
vyznamenání totiž srovnával se svými spolupracovníky z hejtmanství, např. se správcem berního referátu Františkem Seifertem a okresním lékařem MUDr. Ladislavem Naxerou. Kramoliš sice vyznamenání přijal, ale nenosil je. Po válce pak byli vyznamenaní okresní školní inspektoři ostrakizování v pedagogickém časopise Komenský (Vyznamenaní inspektoři školní, 1919, s. 6). Kramoliš se proti návrhưm na jejich odvolání ohradil textem zaslaným do téhož periodika (Kramoliš, 1919, s. 5). Poukázal právě na nízký typ vyznamenání, které podle něj nebylo oceněním práce učitelstva, ale spíše jeho dehonestací.

Nepodepsaný článek se seznamem vyznamenaných inspektorů byl součástí ostré kampaně v časopise Komenský vedené proti okresním školním inspektorům po zániku Rakouska-Uherska od listopadu 1918 do konce roku 1919 (např. Účtování, 1918, s. 5; Očista, 1918, s. 4; Konečně kus očisty, 1919, s. 6). Tyto texty odrážely turbulence ve školních úřadech započaté v listopadu a prosinci 1918 žádostmi učitelů některých okresů o okamžité odstranění inspektorů, někdy také hejtmanů a strážmistrů (Školní inspektor Nápravník, 1918, s. 5). Než se situace uklidnila, objevovaly se další požadavky na očistu školství, přičemž u žádného textu nebyl uveden autor.

Vedle Kramoliše je v seznamu (Vyznamenaní inspektoři školní, 1919, s. 6) jmenován také Josef Okoun, okresní školní inspektor a ředitel dívčí měštanské školy v Bzenci. V roce 1919 otiskl časopis Komenský více článků s popisem konkrétních př́hod jeho bezohledného chování vưči podřízeným učitelům (Inspektor Okoun, 1919, s. 5-6; Kterak za plnění, 1919, s. 3; Kterak se kdo může, 1919, s. 8). V dalších zprávách pak byla uváděna jména moravských inspektorů, jimž bylo vytýkáno prorakouské smýšlení a perzekuce učitelů. Jedním z nich byl například Jan Vincent z Nového Jičína, autor prorakouské vlastenecké brožurky určené mládeži (Vincent, 1916; Učitelstvo okresu novojického, 1918, s. 5). Proti inspektorovi a řediteli učitelského ústavu prof. Vladimírovi Janků z Kroměříže dokonce studenti uspořádali jednodenní stávku (blíže Zezulová, 2014, s. 36-40; srov. Nutno čísti, 1919, s. 5).

$\mathrm{V}$ převratné době po vzniku nového státního útvaru, kdy se zásadně proměnila pravidla pro posuzování loajálního chování okresních školních inspektorů, však byli někteří inspektoři obviněni neprávem. 
Proti článku o Aloisi Lhotském, řediteli měštanské školy v Třešti (ZJihlavska, 1919, č. 7, s. 6), se ohradili sami učitelé regionu a vyzvali k vypsání konkrétních př́kladů (Z Jihlavska, 1919, č. 9, s. 6), kdy odmítl pomoci učiteli nebo je šikanoval. Na výzvu se nepřihlásil nikdo, ani pisatel článku, a předsednictvo učitelského spolku Budeč jihlavská se plně postavilo za inspektora Lhotského (Z okresu jihlavského, 1919, č. 15, s. 6). Časopis Komenský také uveřejnil zprávu, že podle věrohodných zdrojů výroky o rakušáctví a byrokratismu křivdily inspektorovi boskovického okresu Jaroslavu Traplovi (Z boskovského okresu, 1918, s. 8). Mezi ty, kteří byli nařknuti neprávem, patřil i Čeněk Kramoliš, který se obhájil sám v již zmíněném článku (Kramoliš, 1919, s. 5).

Debata o činnosti inspektorů dospěla na podzim roku 1919 až k uveřejnění návrhu na úplné zrušení inspektorského úřadu (Svoboda, 1919, s. 5-6). Reakce učitelů byly různé. Objevil se jak zamítavý postoj s argumenty, proč je nutné inspektory zachovat (Kosík, 1919, s. 36-37), tak nadšený souhlas (Kautman, 1919, s. 84-85). Veškerý rozruch kolem válečné činnosti okresních školních inspektorů v roce 1920 utichl. Nejpalčivější případy vyřešilo jmenování nových inspektorů, mnozí další byli ve funkci okresního školního inspektora potvrzeni, nebot’ jejich činnost nebyla shledána jako učitelưm nepřátelská či závadná.

Kramoliš se snažil být vždy určitým nárazníkem mezi nařízeními státních úřadů, během války zejména vojenských, a skutečnými potřebami učitelů a škol. Jako renomovaný spisovatel se v atmosfére charakterizované na jedné straně euforií z konce války a z nově nabyté svobody, na druhé hledáním, označováním a odstraňováním všeho spojeného se starým Rakouskem, rozhodl svou válečnou činnost zaznamenat a později vydat tiskem. Jedním z důvodů byla snaha obhájit inspektory, kteří během válečných let usilovali o zachování dobré úrovně školství. Jeho soukromá korespondence s učiteli z válečných let, která by osvětlila podrobnosti vzájemných vztahů s inspektorem, se bohužel nedochovala.

Čeněk Kramoliš působil jako inspektor i po vzniku nové Československé republiky až do roku 1924, kdy byl funkce zproštěn ze zdravotních důvodů. V roce 1925 byl přeložen do penze (Kramoliš, 1948, s. 135-136). Také v průběhu poválečných let pokračoval v péči o rozvoj 
školství. I nadále učitele při inspekci velmi přísně hodnotil $\mathrm{z}$ hlediska prospěchu žáků a správné pedagogické metody. Vyžadoval i pořádek ve vedení úředních knih. Zůstal však věrný také své zásadě řešit konflikty a nedostatky nejprve osobní domluvou a výtkou, než začal uvažovat o disciplinárním řízení. Postupoval tak i v případě nahlášeného přestupku učitele Františka Dohnala ve škole v Drahotuších. Dohnal sloužilv armádě po celou dobu války a dosáhl hodnosti poručíka. Po návratu měl potíže adaptovat se znovu na prostřední školy. Rodiče si na něj stěžovali kvưli bití žáků. Okresní školní inspektor jej důrazně upozornil, že použivání tělesných trestů ve škole zakazuje zákon a při dalším hlášení už učitele chránit nebude (Kovářová, 2014, s. 30). Dohnal vyučoval v Drahotuších až do roku 1929, a to již bez dalších podobných stížností.

\section{Závěr}

Je zřejmé, že život školního inspektora neznamenal jen dưkladné seznámení se s geografií svého okresu, ale zejména se školním životem a životem učitelů. Inspektoři kontrolovali jak chod vyučování, tak tzv. život školního společenství (spolupráci školy s obcí, školní život -výstavy, divadelní či jiná představení, aktivity mimoškolní apod.). V tomto ohledu inspektoři dbali nejen o naplňování nařízení daných státní byrokracií v oblasti školství, ale rovněž mohli podporovat spontánnější a aktivnější život škol - v rámci komunity i s ohledem na rozvoj reformních vyučovacích snah. Inspektor tak, jako moc dohlížecí a kontrolující, významnou měrou přispíval ke stavu okresního školství. Byl přímým aktérem jeho řízení i možného rozvoje. Byl osobou, která z velké části dávala „tváŕ“ a směr školám daného okresu. Inspekce nejen určovala pedagogické normy, ale rovněž sehrávala důležitou roli $\mathrm{v}$ „kontrole i ochraně“ učitelů před vnějšími (politickými, společenskými) podmínkami či dopady zásadních politicko-společensko-kulturních proměn. $Z$ tohoto pohledu byla práce inspektora nejen odborně pedagogická, ale rovněž společensko-politická. Je zřejmé, že zatímco v odborné rovině se snáz nacházela shoda, dle jakých norem a pohledů byla práce učitele a školy kontrolována, naopak v politicko-společenských záležitostech se mnohem více ukazovalo, jakou osobností inspektor byl a jaká politicko-společenská přesvědčení zastával. Pohled na profesní život 
inspektora v době monarchie, v době první světové války a v období po vzniku Československa rovněž poodkrývá další důležité pohledy na fungování školství a školské správy na přelomu 19. a 20. století. Školní inspektoři, ještě více než učitelé, v sobě pravděpodobně zpracovávali nemalé př́ípadné vnitřní rozpory, když jejich loajalita musela směrovat jak ke státní moci, tak i k národnímu uvědomění a cítění, když se jejich politické nahlížení mohlo významněji lišit od „požadovaného“ smýšlení. Inspektoři byli symbolem státní kontroly ve školství, a tedy i „ztělesněním“ státem požadovaných „norem“. Na druhé straně byli těmi, kteří požadavkům a očekáváním státní byrokracie nedokázali vždy vyhovět. Osobnost a inspektorská činnost Čeňka Kramoliše tyto rozpory důležitým způsobem dokládá.

\section{Archivní zdroje}

OÚ Hranice, kart. č. 32, inv. č. 604, sign. 532. SOkA Přerov.

OÚ Hranice, kart. č. 25, inv. č. 602, sign. 348. SOkA Přerov.

OŠV Hranice, kart. č. 47, inv. č. 156. SOkA Přerov.

OŠV Hranice, kart. č. 84, inv. č. 196. SOkA Přerov.

OŠV Hranice, kart. č. 86, inv. č. 199. SOkA Přerov.

OŠV Hranice, kart. č. 99, inv. č. 218. SOkA Přerov.

ZŠ Velká, inv. č. 7. SOkA Přerov.

\section{Literatura}

BARTOŠOVÁ, Jana, ŠIMEK, Jan \& ŠUSTOVÁ, Magdaléna, 2019. Od školdozorce k inspektorovi: historie školní inspekce. Praha: NPMK. ISBN 978-80-86935-46-1.

BARTOVSKÝ, Vojtěch, 1906. Hranice: Statisticko-topografický a kulturně-historický obraz spolu s úplným adressářem. Hranice, s. 129-154.

BEDNÁŘ, Václav, INDRA, Bohumír \& Lapáček, Jiří, 2004. Kronikáři města Hranic. Hranice, s. 94-98.

Inspektor Okoun, 1919. Komenský. Roč. 46, č. 25, s. 5-6.

Jubileum, 1912. Moravská orlice, 2. 12. 1912, s. 2-3.

KADLEC, Petr, 2017. K otázce jazykové, etnické a národnostní skladby obyvatel Hranic a Hranicka před vznikem Československa. In: Sbornik Státního okresniho archivu Přrovov. Přerov, s. 71-84. 
KAUTMAN, František, 1919. K diskusi o otázce dozoru na školách. Komenský. Roč. 47, č. 6, s. 84-85.

Konečně kus očisty moravského školství, 1919. Komenský. Roč. 46, č. 24, s. 6. KOSÍK, Em., 1919. Otázka dozoru na školách. Komenský. Roč. 47, č. 3, s. 36-37.

KOVÁŘovÁ, Helena, 2012. Čeněk Marák. In: Základní škola Drahotuše: Almanach ke 100. výročí otevření školní budovy. Drahotuše, s. 78-81.

KOVÁŘOVÁ, Helena, 2014. Velká válka a vesnické školy na př́ikladu Drahotušska. In: KLÍMOVÁ, Jarmila (ed.). Škola a velká válka. Přerov, s. 25-32.

KRAMOLIŠ, Čeněk, 1911. Př́ručka pro učitele, místní a c.k. okresní školni rady: Prakt. doplněk k Př́ruční knize školních zákonuv a předpisưv. Brno.

KRAMOLIŠ, Čeněk, 1919. Vyznamenaní inspektoři školní. Komenský. Roč. 46, č. 10, s. 5.

KRAMOLIŠ, Čeněk, 1924. Válečné vzpomínky školního inspektora. Zábřeh.

KRAMOLIŠ, Čeněk, 1948. Vzpomínky z učitelského a spisovatelského života. Olomouc.

Kterak se kdo může ve školství snadno vyšinouti: Z ilustračních anekdot okounských, 1919. Komenský. Roč. 47, č. 1, s. 8.

Kterak za plnění povinností může býti člověk ještě trestán, 1919. Komenský. Roč. 46 , č. 26 , s. 3.

NEBESKÝ, Jiří J. K. (ed.), 2010. Kroniky obce Velké. Velká - Hranice.

NOVOTNÝ, Ludvík, 1969. 1. světová válka, 28. říjen 1918 na Hranicku. Hranice.

Nutno čísti!, 1919. Komenský. Roč. 46, č. 7, s. 5.

POHAN, 1919. K inspektorské otázce. Komenský. Roč. 46, č. 9, s. 3.

SKÝPALA, Otakar, 1919. Persekuce moravského učitelstva za války. Komenský. Roč. 46 , č. 10 , s. 3.

SVOBODA, Ludvík, 1919. Otázka dozoru na školách. Komenský. Roč. 47, č. 1, s. 5-6.

Školní inspektor Nápravník z Tišnova před soudem učitelstva, 1918. Komenský. Roč. 46 , č. 4 , s. 5.

Školní hrůzovládce, 1918. Komenský. Roč. 46, č. 5, s. 5-6.

Učitelstvo okresu novojického, 1918. Komenský. Roč. 46, č. 4, s. 5.

Účtování se školními hrůzovládci, 1918. Komenský. Roč. 46, č. 4, s. 5.

VINCENT, Jan, 1916. Několik myšlenek o světové válce: slovo učitele k dospělejší mládeži rakouské. Třebíč.

Vyznamenaní inspektoři školní, 1919. Komenský. Roč. 46, č. 7, s. 6.

Z boskovského okresu, 1918. Komenský. Roč. 46, č. 6, s. 8. 
Z Jihlavska, 1919. Komenský. Roč. 46, č. 7, s. 6.

ZEZULOVÁ, Jitka, 2014. Velká válka a c. k. ústav ku vzdělávání učitelů v Kroměříži. In: KLÍMOVÁ, Jarmila (ed.). Škola a velká válka. Přerov, s. 33-40. 